\title{
Investigation into the cancer protective effect of flaxseed in Tg.NK (MMTV/c-neu) mice, a murine mammary tumor model
}

\author{
Franziska Kramer Birkved • Alicja Mortensen • \\ José L. Peñalvo • Rikke H. Lindecrona • \\ Ilona Kryspin Sørensen
}

Received: 28 September 2010/Accepted: 25 February 2011/Published online: 16 March 2011

(C) Springer-Verlag 2011

\begin{abstract}
The aim of the present study was to investigate whether low flaxseed doses relevant to human dietary exposure can prevent mammary tumors in transgenic Tg.NK mice, a model of breast cancer. Animals were exposed to flaxseed through the diet at human relevant levels. Tumor-related parameters and tumor development were evaluated. Hepatic cytochrome P450 and glutathione S-transferase activities were significantly reduced in animals receiving low flaxseed doses. An incidence of palpable tumors before sacrifice, a number of tumors per mouse, and a number of large tumors ( $>6 \mathrm{~mm}$ diameter) at necropsy were statistically significantly lower in the high flaxseed group compared to controls, suggesting a beneficial effect on tumor progression of small dietary doses of flaxseed. However, the number of tumor-bearing mice and multiplicity of tumors at necropsy were not statistically significantly lower compared to the controls. Thus, the effect of small dietary doses of flaxseed on mammary tumor development in $\mathrm{Tg}$. NK mice remains to be established.
\end{abstract}

Electronic supplementary material The online version of this article (doi:10.1007/s12263-011-0214-1) contains supplementary material, which is available to authorized users.

F. K. Birkved · A. Mortensen $(\bowtie) \cdot$ R. H. Lindecrona .

I. K. Sørensen

National Food Institute, Technical University of Denmark,

Moerkhoej Bygade 19, 2860 Soeborg, Denmark

e-mail: almo@food.dtu.dk

J. L. Peñalvo

Folkhälsan Research Center, Helsinki, Finland, and Department of Food Technology, CeRTA-UTPV, University of Lleida, 25198 Lleida, Spain
Keywords Lignans · Flaxseed · Mammary tumorigenesis · Tg.NK mice · Hepatic enzymes

$\begin{array}{ll}\text { Abbreviations } \\ \text { End } & \text { Enterodiol } \\ \text { Enl } & \text { Enterolactone } \\ \text { IsoL } & \text { Isolariciresinol } \\ \text { Lar } & \text { Lariciresinol } \\ \text { Mat } & \text { Matairesinol } \\ \text { Pin } & \text { Pinoresinol } \\ \text { Seco } & \text { Secoisolariciresinol }\end{array}$

\section{Introduction}

Breast cancer is the most common form of cancer among the women in the Western world [27]. Epidemiological studies indicate that phytochemicals like flaxseed lignans can protect against mammary cancer [1]. High plasma enterolactone $(\mathrm{Enl})^{1}$, a biomarker of lignan exposure, has been correlated with reduced breast cancer risk [2, 3, 32, 33]. Women with breast cancer have been found to have significantly lower urinary excretion of Enl, which indicates lower intake of dietary lignans compared to healthy women [3, 33]. Enl and enterodiol (End) are produced by the gut flora from plant lignan precursors such as secoisolaricesinol (Seco) primarily found in flaxseed and to a much lesser degree in whole grain cereals, berries, nuts, and fruits [42]. The average daily intake of lignans in Western Europe has been estimated to be between 0.4 and $1 \mathrm{mg}$ per person [2, 3, 5, 13, 41] The potential breast cancer protective effect of lignans could be due to their 
weak estrogenic activity [2, 20, 31, 37] and antioxidant properties [18]. Several animal studies indicate that lignans and/or flaxseed can enhance mammary gland differentiation. [38, 40]. Furthermore, flaxseed has been reported to enhance the inhibitory effect of tamoxifen on the growth of human estrogen-dependent mammary cancer [9, 10].

The present study evaluates the effect of flaxseed on mammary gland morphogenesis and tumor development in the Tg.NK (mouse mammary tumor virus [MMTV]/c-neu) mice. This animal model carries an activated $c$-neu oncogene, a homologue of the human erbB2 oncogene under the control of mouse mammary tumor virus (MMTV) [34]. ErbB2 oncogene is overexpressed in $25-30 \%$ of all human breast cancers [36]. Tg.NK mice develop palpable mammary tumors beginning at the age of 22 weeks without developing tumors in other tissues [34]. This model has been reported as relevant to study dietary prevention of breast cancer and to investigate dietary effects on tumor development. The animals used in the present study were homozygous Tg.NK transgene carriers. The dietary concentrations of flaxseed were aimed to provide intake of lignans comparable to human dietary exposure. The differences in metabolic rates between the mouse and the human were taken into consideration while choosing the dietary concentrations of flaxseed in the experimental diet. In addition, the potential influence of flaxseed on the rate of apoptosis in the developing mammary gland and on the activity of selected drug-metabolizing enzymes was studied.

\section{Materials and methods}

\section{Chemicals}

Flaxseed was kindly supplied from Kampffmeyermühlen AG, Germany. Carmine, NADPH, glutathione, dicoumarol, cytochrome C, menadione, glucose-6-phosphate, glucose6-phosphate dehydrogenase, 3-amino-9-ethylcarbazole, and HEPES (N-[2-Hydroxyethyl]piperazine- $\mathrm{N}^{\prime}$-[2-ethanesulfonic acid]) were from Sigma Chemical Co. (St. Louis, MO, USA). Beta-glucuronidase/sulfatase (Helix pomatia, 5.5 and $2.6 \mathrm{U} / \mathrm{ml}$, respectively) was purchased from Boehringer Mannheim (Mannheim, Germany). Bicinchoninic acid (BCA) protein assay reagent was obtained from Pierce Chemical Company (IL, USA). 1-Chloro-2,4-dinitrobenzene was from Riedel-de-Häen (Seeize, Germany). Pentoxyresorufin, ethoxyresorufin, and resorufin were from Molecular Probes Europe B. V. (Leiden, The Netherlands), Meyer's hematoxylin and Putts eosin from Prohosp (Denmark) and Eukitt from Bie and Berntsen (Denmark). LMPCR assay for apoptosis was purchased from Clontech Kit \# K 905-1.
Animal, housing, and clinical observations

Tg.NK female mice approximately 3 weeks of age and weighing $12.6 \mathrm{~g} \pm 1.6$ (mean $\pm \mathrm{SD}$ ) were obtained from Taconic Farms, Inc., Germantown, NY, USA. All Tg.NK mice were housed $2 /$ cage. Upon the arrival until the start of the experiment, the Tg.NK mice were fed a control semisynthetic diet (Table 1). In order to prevent the occurrence of anoestrus, four male NMRI mice approximately 4 weeks old were placed in the same room as Tg.NK female mice. The males were obtained from Bommice Bonholtgaard Breeding and Research Center LTD, Rye, Denmark, housed 1/cage, and fed Altromin 1324 diet (Altromin International, Lage, Germany). All mice were kept under controlled environmental conditions (temperature $21 \pm 1^{\circ} \mathrm{C}$, the relative humidity $55 \pm 5 \%, 12 / 12 \mathrm{~h}$ light/ dark cycle, air changed 10 times/h) and had free access to feed and water acidified to $\mathrm{pH} 3.0$ by citric acid (to prevent growth of microorganisms). Body weight and feed intake were recorded weekly once for female Tg.NK mice. All mice were observed at least twice a day for any abnormalities in clinical appearance.

The animal study was performed under conditions approved by the Danish Agency for Protection of Experimental Animals and by the in-house Animal Welfare Committee.

Tumor study

The animals were randomized into four groups $(N=21 /$ group) based on body weight and fed ad libitum the experimental diets from the 25th day of life for 23 consecutive weeks: group 1 (control) a semi-synthetic diet (Table 1), groups 2-4 this semi-synthetic diet added either 60,180 , or $540 \mathrm{mg}$ flaxseed $/ \mathrm{kg}$ diet. Starting at the 15 th week of life, the animals were palpated twice a week for the presence of subcutaneous tumors. At termination, all the remaining Tg.NK mice were anaesthetized by intraperitoneal injection of a pentobarbital solution $(60 \mathrm{mg} / \mathrm{kg}$ bw). From an uncovered thoracic cavity, blood samples

Table 1 Composition of the control semi-synthetic diet

\begin{tabular}{|c|c|}
\hline Component & $\mathrm{g} / \mathrm{kg}$ \\
\hline Carbohydrates & 680 \\
\hline Casein & 180 \\
\hline Cellulose & 60 \\
\hline Soy bean oil ${ }^{\mathrm{a}}$ & 40 \\
\hline Mineral mixture & 33 \\
\hline Vitamin mixture & 9 \\
\hline
\end{tabular}

${ }^{a}$ The major fatty acids in the oil were C 18:2 linoleic and 18:3 linolenic (51.05 and $8.0 \%$ of all fatty acids, respectively; ratio $n-6 / n-3$ of 6.4) 
were collected by heart puncture and stabilized in heparin. After bleeding to death, the ventral skin was reflected and visible subcutaneous tumor masses were counted, measured, removed, and fixed in $4 \%$ neutral buffered formaldehyde. The thoracic and abdominal cavities were examined for gross lesions. Liver was removed and weighed. All the subcutaneous tumor masses were processed, embedded in paraffin, sectioned at $5 \mu \mathrm{m}$, and stained with hematoxylin and eosin for light microscopic examination. Tumor burden was reported as the number of tumors per mouse and multiplicity (number of tumors per tumor-bearing mouse).

\section{Study of mammary gland development}

Additional 10 animals per group fed the respective diets for 2 or 6 weeks were sacrificed by barbiturate intraperitoneal injection $(60 \mathrm{mg} / \mathrm{kg}$ bw) followed by heart blood extraction. The age at the sacrifices was approx. 6 or 10 weeks. All the 10-week-old animals were sacrificed at estrus stated by examination of vaginal smear. Blood samples were separated into plasma and red blood cells (RBC) and stored at $-80^{\circ} \mathrm{C}$ for further analysis. Liver was excised, rinsed in saline phosphate buffer (PBS), weighed, snap-frozen in liquid $\mathrm{N}_{2}$, and stored at $-80^{\circ} \mathrm{C}$. Fourth abdominal gland was excised, placed on an object glass, dried for $5 \mathrm{~min}$, and fixed in Carnoy's fixative (75\% ethanol, $25 \%$ glacial acid) for $2 \mathrm{~h}$ followed by staining with carmine alumina according to Thomsen et al. [39].

The differentiation pattern and development of the 4th abdominal mammary gland were analyzed by quantifying the different structures in the mammary gland in ten representative areas of the gland of animals older than 6 weeks and the whole gland in 6-week-old animals, by measuring the longitudinal growth of the gland and by quantifying the degree of branching using a light microscope equipped with ocular micrometer. Structures were defined based on the classification of Brown and Lamartiniere [7]: terminal end buds (TEB) were recognized by having 3-6 epithelial layers and a diameter of more than $100 \mu \mathrm{m}$, terminal ducts (TD) were less than $100 \mu \mathrm{m}$ in diameter and consisted of a single cell layer, alveolar buds (AB) were identified as terminal or lateral buds further differentiated into 2 or more smaller buds and lobuli as structures consisting of more than $5 \mathrm{AB}$.

Determination of hepatic phase 1 and 2 enzymes

The microsomal and cytosolic fractions of the liver were prepared as described by Lake [21] and stored at $-80^{\circ} \mathrm{C}$ until use. The microsomes were characterized by the specific activities of major cytochrome P450 (CYP) enzymes as described by Burke et al. [8] with modifications as described by Breinholt et al. [6]. The activities of the CYP isozymes $1 \mathrm{~A} 1 / 2,3 \mathrm{~A} 4,2 \mathrm{~B} 1 / 2$ in the microsomal liver fraction were assayed using ethoxyresorufin, benzyloxyresorufin, methoxyresorufin and pentoxyresorufin (EROD, BROD, MROD and PROD), respectively. Hepatic glutathione S-transferase (GST) was analyzed in hepatic cytosol as described by Ernster [15] and Habig et al. [16]. The protein concentration was determined by either a commercially available kit or the bicinchoninic acid method [35] adapted to a Cobas Mira (Roche) in case of protein concentrations below $10 \mathrm{mg} / \mathrm{ml}$.

Detection of nucleosomal ladders in the fourth abdominal mammary gland by LM-PCR and their densitometric quantitation of DNA from the abdominal mammary gland was isolated according to Ausbel et al. [4]. The detection of the apoptotic nucleosomal DNA ladders in the abdominal mammary gland was made as previously described by Dalgaard et al. [12]. In short, during apoptosis, cellular endonucleases cleave genomic DNA between nucleosomes, producing fragments whose lengths vary by multiples of 180-200 bp. When resolved by agarose/EtBr gel electrophoresis, these DNA fragments appear as a "nucleosomal ladder." The ligation-mediated PCR (LMPCR assay from Clontech Kit \# K 905-1) that uses PCR reaction to specifically amplify the nucleosomal ladder, making it easier to visualize, was used. The densitometric analysis of apoptotic banding pattern obtained by LM-PCR was performed using the densitometer software (Alpha Ease $^{\mathrm{TM}}$, Alpha Innotech, San Leandro, CA). Using this densitometer software, outlines with equivalent areas were drawn around the bands and the intensity of the total area was determined.

Analysis of lignans in plasma samples and diets

Metabolic profile of lignans in plasma samples obtained from each animal at the termination of tumor study was carried out after enzymatic hydrolysis by HPLC with coulometric electrode array detector following a previously published method [29, 30]. Enterolignans, Enl and End, formed by gut microflora from dietary precursors such as Seco, Mat, Lar and Pin were used as a biomarker of exposure to dietary lignans. The lignan content of the diets and in flaxseed was determined by isotope dilution GC-MS as reported [29, 30].

\section{Statistics}

Data are presented as group mean values plus standard deviation when appropriate. Before subjected to further analysis, the data on body weight, feed intake, liver weight, and tumor size were tested for normal distribution, and the homogeneity of variance among the groups was evaluated 
by judgment of standardized residuals plot. The data on body weight and feed intake were analyzed by GLM analysis followed by Dunnett's test. Data on number of tumors per mouse and tumor size were analyzed by Kruskall-Wallis test. Data on tumor incidence were analyzed by Fischer exact test and data on survival using the lifetest procedure. A one-way analysis of variance was used to compare data on mammary gland development and enzyme data. For the statistical analysis of the relative apoptotic density, Mann-Whitney test was employed. All Statistical analyses were performed using SAS v. 6.08 (SAS Institute, Inc., Cary, NC, USA).

\section{Results}

Lignan content in diets, flaxseed, and plasma

Seco was the predominant lignan in the flaxseed and the only lignan, in which concentration was increased with increasing concentrations of flaxseed in the diet (Table 2). The concentrations of matairesinol (Mat) and pinoresinol (Pin) were comparable in all flaxseed-added diets. The concentration of larciresinol (Lar) in the flaxseed-added diets was similar to that in the control diet.

Plasma Enl concentrations were near detection limits [29, 30]. Although the dietary exposure to Seco was different between groups as confirmed by the diet analysis (Table 2), plasma Enl concentrations were similar in animals receiving control and flaxseed-added diets: $3.22 \mathrm{nM} \pm 0.28$ (SD) in the control, $3.55 \mathrm{nM} \pm 0.23$ in the low-dose group, $2.87 \mathrm{nM} \pm 0.21$ in the middle-dose group, and 2.81 $\mathrm{nM} \pm 0.06$ in the high-dose group. Since plasma Enl concentration did not reflect the differences in Seco intake, the plasma concentration of End, the precursor of Enl, was measured: $42.03 \mathrm{nM} \pm 2.68$ (SD) in the control, 95.64 $\mathrm{nM} \pm 0.12$ in the low-dose group, $57.59 \mathrm{nM} \pm 0.28$ in the middle group, and $83.80 \mathrm{nM} \pm 0.22$ in the high-dose group. The plasma concentration of enterolignans (Enl and End) was $45 \mathrm{nM}$ in the control group. The concentrations of enterolignans in all the flaxseed groups were comparable: 99,

Table 2 Measured concentrations of lignans in the experimental diets and in the flaxseed $(\mu \mathrm{g} / 100 \mathrm{~g})$

\begin{tabular}{lllll}
\hline & Seco & Mat & Lar $^{\mathrm{a}}$ & Pin \\
\hline Control diet & 4.98 & 0.25 & 21.37 & 1.90 \\
Low flaxseed diet & 5.41 & 1.13 & 21.43 & 5.45 \\
Middle flaxseed diet & 20.38 & 1.00 & 20.04 & 4.98 \\
High flaxseed diet & 87.02 & 1.08 & 22.72 & 5.30 \\
Flaxseed & 609,346 & 3,565 & 26,148 & 12,134 \\
\hline
\end{tabular}

${ }^{a}$ The sum of Lar and Lar decomposition product isolariciresinol (IsoL) content
61 and $87 \mathrm{nM}$ in the low, middle and high flaxseed diet groups, respectively. The plasma levels of enterolignans in the flaxseed-exposed groups did not reflect the difference in lignan content of the flaxseed-added diets.

Clinical appearance, body weight, and survival

The clinical appearance of Tg.NK mice did not differ among the groups. With regard to behavior, the Tg.NK mice appeared very active and tended periodically to run in circles. Body weight of mice on diets added low, middle or high concentration of flaxseed were comparable to those of mice fed a control diet from the start of the experimental feeding until the termination (Table 3 ). The feed intake was comparable between all groups.

In the control group, four mice died prior to the terminal sacrifice: on days 108, 115, 122, and 128 of treatment (Fig. 1). All the mice were tumor-negative. On day 139, one control tumor-positive mouse was euthanized due to ethical reasons. In the low flaxseed group, four mice died prior to the terminal sacrifice: on days 101,119, 120, and 147. All the mice were tumor-negative. In the middle flaxseed group, two mice died prior to the terminal sacrifice: on days 106 and 112. The mice were tumor-negative. In the high flaxseed group, six mice died prior to the terminal sacrifice: on days 95, 96, 103, 120, 122, and 123. All the mice were tumor-negative. The number of mice surviving to the terminal sacrifice was $16,17,19$ and 15 in the control, low, middle and high flaxseed groups, respectively.

\section{Tumor development}

The pattern of palpable tumor incidence is presented in Fig. 2.

The first palpable tumors were recorded from day 134 (week 19) of treatment. The last examination of tumor development by palpation was on day 157 (week 22) of treatment. The incidence of palpable tumors on that day was significantly lower in the high flaxseed group compared to the control group (1 animal vs. $10, P<0.01$ ) (Fig. 2).

Macroscopic examination did not reveal tumors in other tissues than mammary glands. The incidence of mammary tumors recorded at necropsy was not statistically significantly different between the groups (Table 4). The number of tumors per mouse was statistically significantly lower in the high flaxseed group, but multiplicity of tumors (number of tumors per tumor-bearing mice) was not significantly different between the groups. In addition, mice from the high flaxseed group receiving the highest dose of flaxseed had a statistically significantly lower number of big tumors i.e., tumors bigger than $6 \mathrm{~mm}$ in diameter compared to control animals $(P<0.01)$ (Fig. 3). 
Table 3 Body weight, feed intake, and liver weight of animals in the tumor study

\begin{tabular}{|c|c|c|c|c|c|c|c|}
\hline \multirow{2}{*}{$\begin{array}{l}\text { Group/dose } \\
\text { of flaxseed }\end{array}$} & \multicolumn{2}{|c|}{ Number of animals } & \multicolumn{2}{|c|}{ Body weight (g) } & \multirow{2}{*}{$\begin{array}{l}\text { Feed intake } \\
\text { (g/animal/week) }\end{array}$} & \multicolumn{2}{|l|}{ Liver weight } \\
\hline & Start & $\begin{array}{l}\text { Scheduled } \\
\text { termination }\end{array}$ & Initial & $\begin{array}{l}\text { Scheduled } \\
\text { termination }\end{array}$ & & Absolute (g) & Relative \\
\hline Control & 21 & 16 & $17 \pm 1.3$ & $27 \pm 2.6$ & $23 \pm 1.2$ & $1.1 \pm 0.08$ & $4.0 \pm 0.29$ \\
\hline Low & 21 & 17 & $17 \pm 1.3$ & $27 \pm 1.9$ & $22 \pm 0.4$ & $1.0 \pm 0.08$ & $3.8 \pm 0.23$ \\
\hline Middle & 21 & 19 & $17 \pm 1.5$ & $28 \pm 3.2$ & $24 \pm 1.1$ & $1.1 \pm 0.12$ & $3.8 \pm 0.63$ \\
\hline High & 21 & 15 & $17 \pm 1.5$ & $27 \pm 2.5$ & $25 \pm .1 .2$ & $1.1 \pm 0.10$ & $4.1 \pm 0.48$ \\
\hline
\end{tabular}

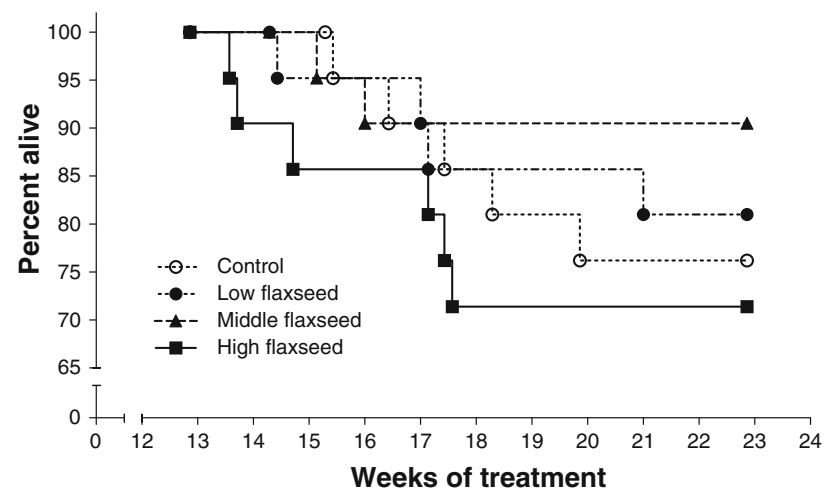

Fig. 1 Survival of Tg.NK mice. $(P>0.5$, lifetest procedure)

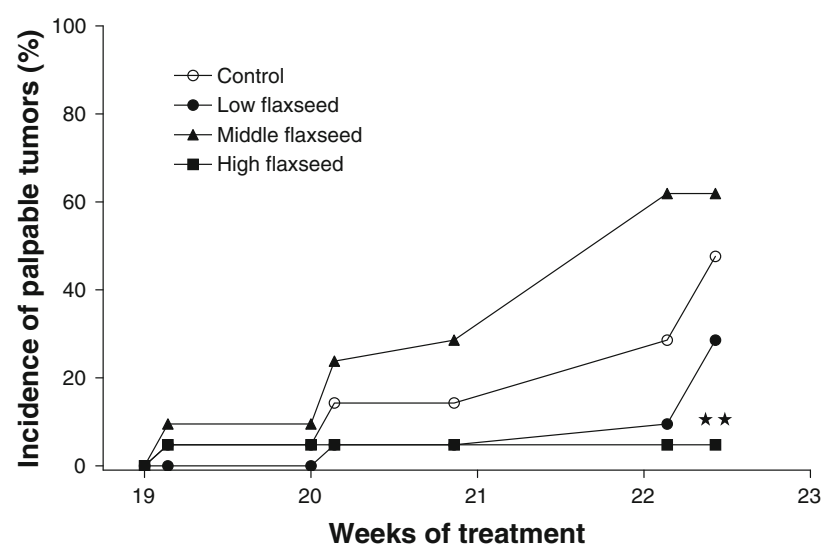

Fig. 2 The percent incidence of palpable mammary tumors per week and treatment group is shown. $* * P<0.01$ (Fischer exact test)

Histopathological examination of mammary tumors indicated that all mammary tumors could be classified as adenocarcinoma. Tumors usually consisted of solid sheets with cystic spaces filled with tissue fluid, blood, or debris.

Effects on mammary gland development

No differences in mammary gland development as assessed by branching, longitudinal growth, and differentiation were recorded between the flaxseed diet groups compared to the control group (Fig. 4a, b). Within the same group, a statistically significant increase in the size of the mammary gland from week 6 to week 10 of age was recorded (Fig. 5): the gland size was more than double in 10-weekold animals reflecting a physiological development of the gland from weaning until adulthood.

Effects on apoptosis within the mammary gland

Apoptosis in the mammary gland was found to decrease with increasing age. Variation in apoptotic levels between animals was high, and no differences between exposure groups were detected (data not shown).

Effects on activity of hepatic phase 1 and 2 enzymes

A statistically significant increase in cytochrome P450 isozymes activities CYP1A1 and 1A2 (EROD and MROD) was recorded in 10-week-old mice exposed to the low dietary dose of flaxseed (Fig. 6).

Hepatic GST activity was statistically significantly decreased in animals receiving the middle and high doses of flaxseed compared to the controls $(P<0.05)$ (Fig. 7).

\section{Discussion}

Several epidemiological studies indicated that a high lignan intake had a protective effect against breast cancer. As $20-40 \%$ of all human mammary tumors overexpress erbB-2 [36], the Tg.NK mouse model that carries an activated analogue, the c-neu oncogene, driven by the mouse mammary tumor virus (MMTV) promoter [25] was chosen as a relevant model for studying in vivo effects of flaxseed on the development of $c$-neu/ErbB-2/HER-2-positive tumors. A semi-synthetic diet was used in the present study to prevent that phytochemicals like phytoestrogens, isoflavones, and lignans commonly present in standard fixed open formula laboratory chows based on plant ingredients could influence the outcome of the experiment in which low 
Table 4 Mammary tumor incidence and number

\begin{tabular}{|c|c|c|c|c|c|c|c|}
\hline \multirow{2}{*}{$\begin{array}{l}\text { Group/dose } \\
\text { of flaxseed }\end{array}$} & \multicolumn{2}{|c|}{ Number of mice } & \multirow[b]{2}{*}{ No. } & \multicolumn{2}{|c|}{ Tumor-bearing mice } & \multicolumn{2}{|c|}{ Number of tumors per mouse } \\
\hline & Start & Termination & & $\begin{array}{l}\% \text { of all mice } \\
\text { at risk }\end{array}$ & $\begin{array}{l}\% \text { of surviving to } \\
\text { the termination }\end{array}$ & All mice at risk & Mice with tumors \\
\hline Control & 21 & 16 & 16 & 76 & 100 & $4.24 \pm 3.67^{\mathrm{a}}$ & $5.56 \pm 3.20^{\mathrm{a}}$ \\
\hline Low & 21 & 17 & 15 & 71 & 88 & $3.33 \pm 3.35^{\mathrm{a}}$ & $4.67 \pm 3.06^{\mathrm{a}}$ \\
\hline Middle & 21 & 19 & 18 & 86 & 95 & $4.90 \pm 4.56^{\mathrm{a}}$ & $5.72 \pm 4.42^{\mathrm{a}}$ \\
\hline High & 21 & 15 & 12 & 57 & 80 & $1.81 \pm 2.36^{\mathrm{b}}$ & $3.17 \pm 2.33^{\mathrm{a}}$ \\
\hline
\end{tabular}

Means within the same column bearing different superscripts are significantly different $(P<0.05$, analysis of variance with Duncan's multiplerange test)

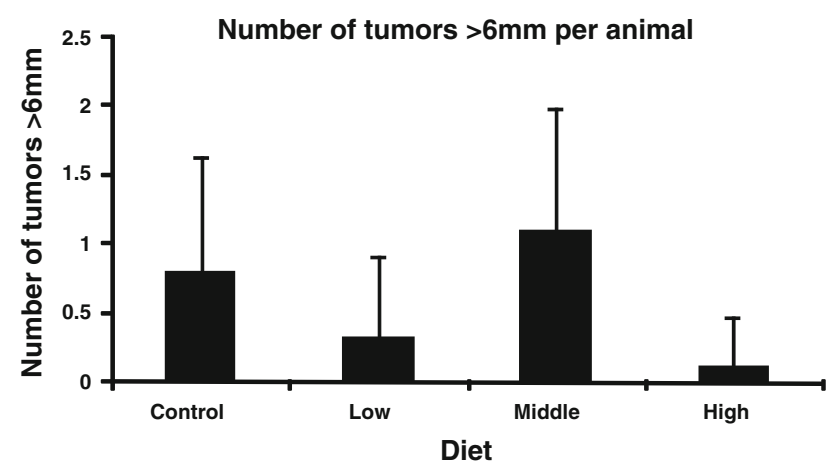

Fig. 3 Number of tumors $>6 \mathrm{~mm}$ found per animal after dietary exposure to the different flaxseed doses $(60,180$, or $540 \mathrm{mg}$ flaxseed per $\mathrm{kg}$ diet referred to as low, middle, and high diet, respectively). Bars indicate the mean $\pm \mathrm{SD}(n=10)$. $* * P<0.01$ (Kruskal-Wallis)

concentrations of flaxseed were used. Flaxseed was used as a dietary lignan source. In addition, flaxseed also contains n-3 polyunsaturated fatty acid (n-3 PUFA) and has been shown to be inversely associated with breast cancer risk [19]. Tg.NK mice fed diets high in n-3 PUFA developed mammary tumors later than when fed n-6 PUFA diets [23]. It has been suggested that the ratio of $n-6 / n-3$ fatty acids may be important in mammary cancer development in Tg.NK mice [23]. However, it is believed that the cancer protective effect of n-3 PUFA can be attributed to a general cancer protective effect and is not specific to mammary cancer in contrast to lignans which is considered due to their estrogenic properties. The dietary exposure of mice to flaxseed was aimed to mimic a one-third, the mean, or three times the mean human dietary exposure to lignans from the Western diet [13]. Thus, the concentrations of flaxseed in the experimental diets were calculated based on the average feed intake by laboratory mouse, the flaxseed content of lignans according to information received from the supplier, and on the difference in metabolic rate between human and mouse applying mouse versus human compensation factor [24]. Analysis of the diets revealed lower content of lignans to what was expected based on the information from the supplier. The analysis further demonstrated that the flaxseed-added diets primarily contained

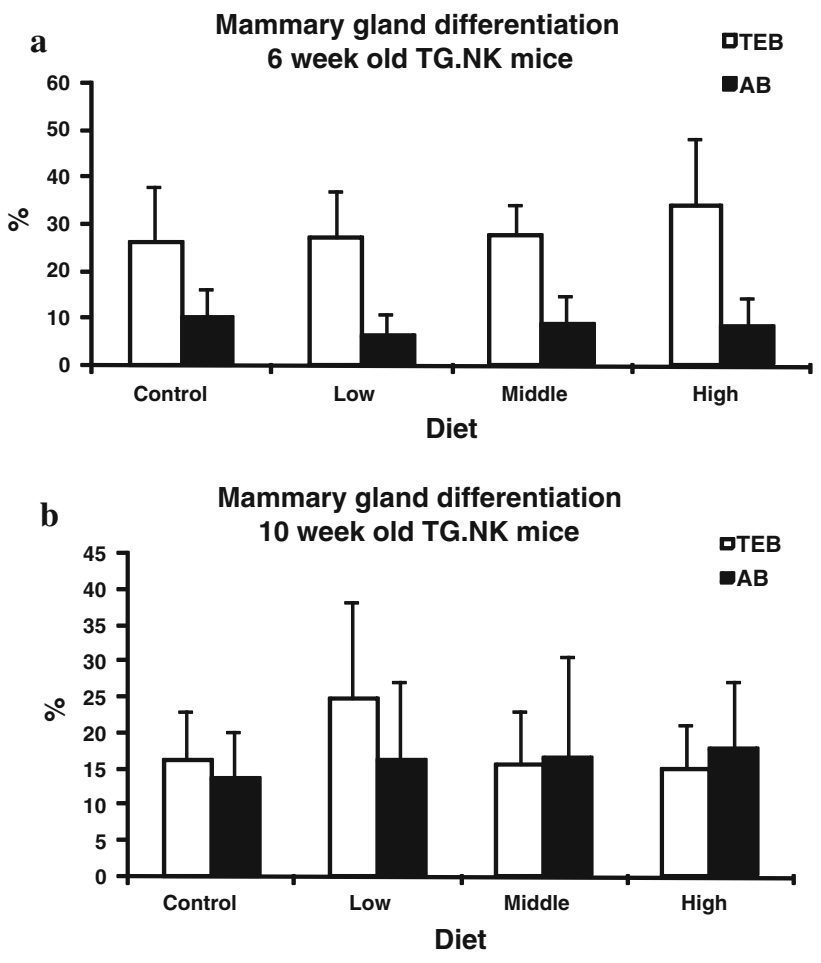

Fig. 4 a Mammary gland differentiation in 6-week-old animals as assessed by the percent of the mammary gland structure representing terminal end buds $(T E B)$ and alveolar buds $(A B)$ in the 4 th abdominal gland for the different treatment groups $(60,180$, or $540 \mathrm{mg}$ flaxseed per $\mathrm{kg}$ diet referred to as low, middle, and high diet, respectively). Bars indicate the mean $\pm \mathrm{SD}(n=10) . P>0.05$ (Dunnetts test). b Mammary gland differentiation in 10-week-old animals assessed by the percent of the mammary gland structure representing terminal end buds $(T E B)$ and alveolar buds $(A B)$ in the 4 th abdominal gland for the different treatment groups $(60,180$, or $540 \mathrm{mg}$ flaxseed per $\mathrm{kg}$ diet referred to as low, middle, and high diet, respectively). Bars indicate the mean $\pm \mathrm{SD}(n=10) . P>0.05$ (Dunnetts test)

two lignans Seco and Lar and only minor amounts of Mat and Pin. However, only the concentration of Seco, a predominant lignan in the flaxseed used, was increased with increasing concentrations of flaxseed in the diet. The measured plasma concentrations of enterolignans indicated an enhanced systemic exposure to lignans in flaxseed groups compared to the control group, but it demonstrated 


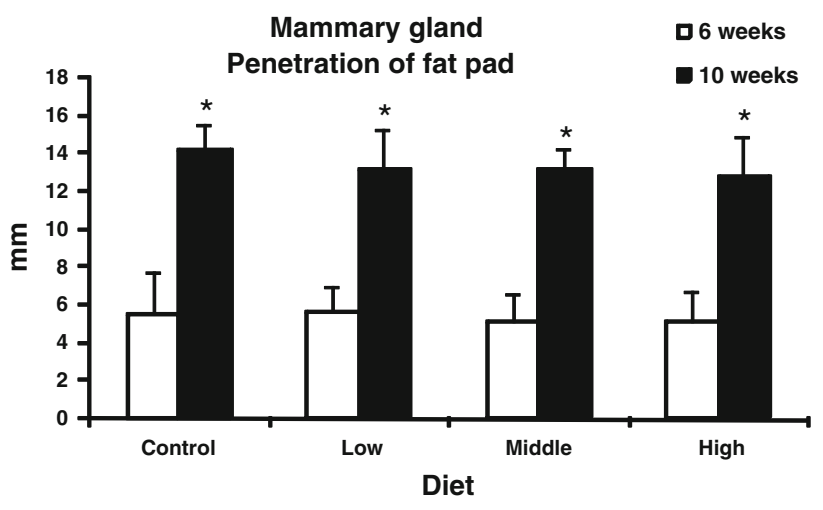

Fig. 5 Penetration of the fat pad by the mammary gland in 6-weekold and 10-week-old animals for the different treatment groups (60, 180 , or $540 \mathrm{mg}$ flaxseed per $\mathrm{kg}$ diet referred to as low, middle, and high diet, respectively). The penetration into the fat pad was measured by a straight line from the outer lymph node of the 4th abdominal gland into the fat pad. Bars indicate the mean \pm SD $(n=10)$. $* P<0.05$ (Dunnetts test)

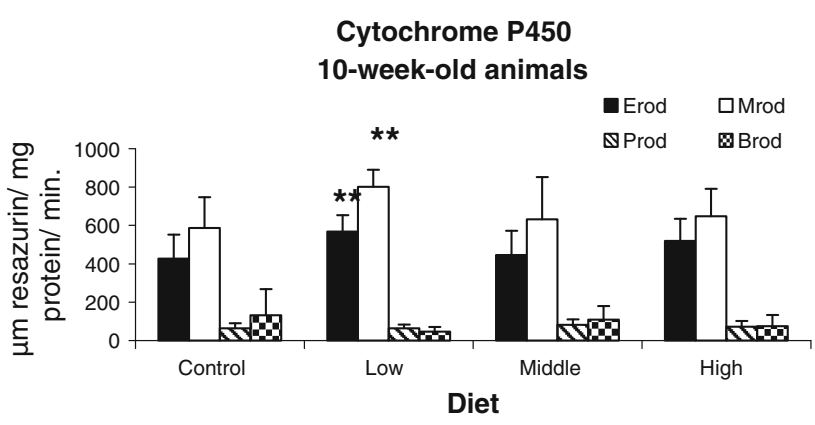

Fig. 6 Cytochrome P450 activities in Tg.NK mice liver microsomes after dietary exposure to the flaxseed doses $(60,180$, or $540 \mathrm{mg}$ flaxseed per $\mathrm{kg}$ diet referred to as low, middle, and high diet, respectively) for 6 weeks (i.e., 10-week-old animals). Cytochrome $\mathrm{P} 450$ activities are expressed in $\mu \mathrm{mol}$ resorufin/mg protein/minute. Bars indicate the mean $\pm \mathrm{SD}(n=10) . * * P<0.01$ (Dunnetts test)

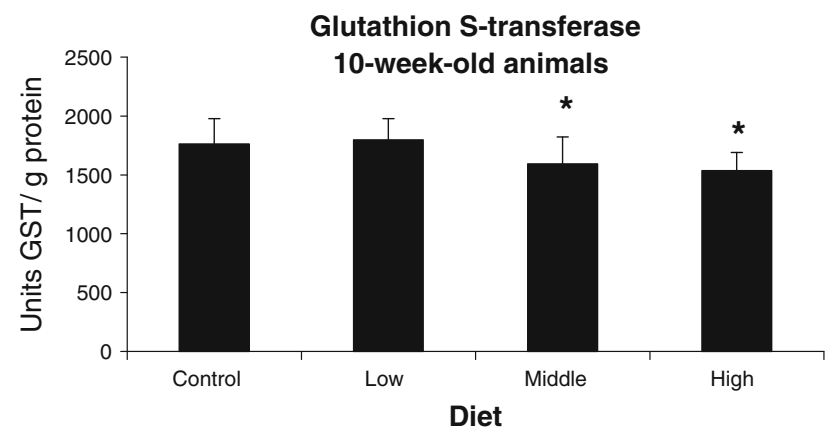

Fig. 7 GST activities in the cytosolic liver fraction of Tg.NK mice after dietary exposure to three flaxseed doses $(60,180$, or $540 \mathrm{mg}$ flaxseed per $\mathrm{kg}$ diet referred to as low, middle, and high diet, respectively)for 6 weeks (i.e., 10-week-old animals). GST activity is expressed in Units GST ( $\mu \mathrm{mol}$ glutathione-conjugate/minute)/g protein. Bars indicate the mean $\pm \mathrm{SD}(n=10)$. ${ }^{*} P<0.05$ (Dunnetts test) lack of the difference in the systemic exposure between the three flaxseed groups probably because of the small differences in the doses. The latter was considered a confounding factor in the interpretation of the results. It is noteworthy, however, that the plasma levels of enterolignans in the mice from flaxseed diet groups were comparable to plasma Enl levels found in humans [32, 44].

In the present study, the dietary exposure to flaxseed had no effect on mammary gland differentiation. It could be speculated that the dietary concentrations were too low to affect age-related maturation of mammary gland. However, much higher dietary concentrations of flaxseed (5 or 10\%) administered to weaned rats had no effect on mammary gland morphogenesis [40]. Several reports indicate that only gestational and/or lactational exposure to flaxseed can alter mammary gland development, whereas exposure after weaning does not influence mammary gland differentiation in rats $[14,17]$.

Cytochrome P450 isozymes play an important role in the metabolism of xenobiotics and are known to play an role in the activation of carcinogens and drug metabolism. They are often induced by the compounds they metabolize, and as cytochrome P450 isozymes are involved in the metabolism of mammalian lignans [26], the effect of flaxseed dietary intake on their activity was of interest. A recorded significantly increased activity of CYP1A1 and $1 \mathrm{~A} 2$ in 10-week-old mice from the low flaxseed group when compared to the control group may indicate that even low dietary exposure to flaxseed can modulate cytochrome P450 isoenzymes. It is, however, noteworthy that the same effect was not detected in the middle- and high-dose groups, and it could speculated if this might have due to with an increasing intake of n-3 PUFA as inhibitory effects of n-3 PUFA toward several CYP isozymes including CYP1A1 and 1A2 have been observed [28, 43]. Thus, an induction of CYP1A1 and 1A2 by lignans might be counteracted by an inhibiting effect of n-3 PUFA in flaxseed, resulting in the observed no effect at the higher dose levels.

Induction of hepatic phase 2 enzymes' activity is considered a cancer protective effect. Although it can be argued whether modulation of xenobiotic metabolism is relevant to tumorigenesis in $\mathrm{Tg}$.NK mice, as tumors in these animals are induced by a genetic alteration rather than a chemical, the inhibition of GST activity in 10-weekold animals exposed to dietary flaxseed concentrations mimicking the average human lignan intake could be of interest. The GST isoenzymes constitute one of the major groups of enzymes involved in the detoxification of both endogenous and exogenous chemicals. A decreased activity of GST in the liver might result in impaired resistance to toxic agents such as oxidants or chemical carcinogens. Information about whether hepatic or red blood cell GST is 
also down-regulated in humans receiving lignan-rich and/ or supplemented diet is needed.

In the present study, apoptosis was found to decrease with increasing age in accordance with physiological mammary gland development; i.e., high proliferation rate during puberty followed by proliferation decrease with age [39] but the dietary exposure to low flaxseed doses did not influence apoptosis as no difference in apoptotic levels was found between exposure groups.

The only tumors observed in the Tg.NK mice were mammary tumors in agreement with a previous report on tumor development in this animal model [34]. A study in nude mice revealed that flaxseed enhanced the inhibitory effect of tamoxifen on the growth of estrogen-dependent human breast cancer [9]. It has been reported that exposure to flaxseed and its purified lignan Seco during lactation inhibited chemically induced mammary carcinogenesis in rats exposed to flaxseed solely [11]. Exposure of Tg.NK mice during post-weaning life to flaxseed added to standard chow or a high-fat diet did not statistically significantly affect the onset and incidence of mammary tumors [22]. In the present study an incidence of palpable tumors at the end of a clinical phase of the experiment (day 157 of treatment), a number of tumors per mouse, and a number of large tumors (i.e., tumors bigger than $6 \mathrm{~mm}$ in diameter) at necropsy were statistically significantly lower in the high flaxseed group compared to the control group. The significantly decreased number of tumors per animal in the high-dose group could indicate a delay in tumor development due to increased exposure to flaxseed. Inhibition of GST at the middle- and high-dose groups could result in increased availability of flaxseed lignans and n-3 PUFA acids resulting from reduced metabolism and excretion of those components. These findings might suggest that dietary exposure to small doses of flaxseed may delay mammary tumor progression. However, in the same flaxseed group, the number of mammary tumor-bearing mice and the multiplicity of tumors recorded at necropsy were not statistically significantly lower compared to the controls. Considering that the plasma levels of enterolignans, though higher than in the control groups, were comparable in all flaxseed groups, the recorded beneficial effects on tumor-related endpoints in the high flaxseed group might be an incidental finding. Therefore, it is concluded that the effect of small dietary doses of flaxseed on mammary tumor development in Tg.NK mice remains to be established.

Acknowledgments The authors thank Margareta Bertram for excellent technical assistance and Anne Ørngreen and her staff for professional handling of animals. This study was supported by grants from the Commission of the European Communities: Fair Program (CT95-0894) and EU-FW5 (QLK1-2000-00266).

\section{References}

1. Adlercreutz H (1995) Phytoestrogens: epidemiology and a possible role in cancer protection. Environ Health Perspect 103(7):103-112

2. Adlercreutz H (2002) Phytoestrogens and breast cancer. J Steroid Biochem Mol Biol 83:113-118

3. Adlercreutz H, Fotsis T, Heikkinen R, Dwyer JT, Woods M, Goldin BR, Gorbach SL (1982) Excretion of the lignans enterolactone and enterodiol and of equol in omnivorous and vegetarian postmenopausal women and in women with breast cancer. Lancet 2:1295-1299

4. Ausbel FM, Brent R, Kingston RE, Moore DD, Sidman JG, Smith JA, Stuhl K (1994) Current protocols in molecular biology. Greene Publishing Associates and John Wiley and Son, NY

5. Boker LK, Van der Schouw YT, De Kleijn MJ, Jacques PF, Grobbee DE, Peeters PH (2002) Intake of dietary phytoestrogens by Dutch women. J Nutr 132:1319-1328

6. Breinholt V, Lauridsen ST, Daneshvar B, Jakobsen J (2000) Dose-response effects of lycopene on selected drug-metabolizing and antioxidant enzymes in the rat. Cancer Lett 154:201-210

7. Brown NM, Lamartiniere CA (1995) Xenoestrogens alter Mammary-Gland differentiation and cell-proliferation in the rat. Environ Health Perspect 103:708-713

8. Burke MD, Thompson S, Weaver RJ, Wolf CR, Mayer RT (1994) Cytochrome-P450 Specificities of Alkoxyresorufin O-Dealkylation in Human and Rat-Liver. Bioche Pharmacol 48:923-936

9. Chen J, Hui E, Ip T, Thompson LU (2004) Dietary flaxseed enhances the inhibitory effect of tamoxifen on the growth of estrogen-dependent human breast cancer (mcf-7) in nude mice. Clin Cancer Res 10:7703-7711

10. Chen J, Power KA, Mann J, Cheng A, Thompson LU (2007) Flaxseed alone or in combination with tamoxifen inhibits MCF-7 breast tumor growth in ovariectomized athymic mice with high circulating levels of estrogen. Exp Biol Med (Maywood) 232:1071-1080

11. Chen J, Tan KP, Ward WE, Thompson LU (2003) Exposure to flaxseed or its purified lignan during suckling inhibits chemically induced rat mammary tumorigenesis. Exp Biol Med (Maywood) 228:951-958

12. Dalgaard M, Nellemann C, Lam HR, Sorensen IK, Ladefoged O (2001) The acute effects of mono (2-ethylhexyl)phthalate (MEHP) on testes of prepubertal Wistar rats. Toxicol Lett 122:69-79

13. De Kleijn MJ, Van der Schouw YT, Wilson PW, Adlercreutz H, Mazur W, Grobbee DE, Jacques PF (2001) Intake of dietary phytoestrogens is low in postmenopausal women in the United States: the Framingham study(1-4). J Nutr 131:1826-1832

14. de AS, Hilakivi-Clarke L (2006) Timing of dietary estrogenic exposures and breast cancer risk. Ann NY Acad Sci 1089:14-35

15. Ernster L (1967) Diaphorese. Methods Enzymol 10:309-317

16. Habig WH, Keen JH, Jakoby WB (1975) Glutathione S-transferase in formation of cyanide from organic thiocyanates and as an organic nitrate reductase. Biochem Biophys Res Commun 64:501-506

17. Hilakivi-Clarke L (2007) Nutritional modulation of terminal end buds: its relevance to breast cancer prevention. Curr Cancer Drug Targets 7:465-474

18. Hu C, Yuan YV, Kitts DD (2007) Antioxidant activities of the flaxseed lignan secoisolariciresinol diglucoside, its aglycone secoisolariciresinol and the mammalian lignans enterodiol and enterolactone in vitro. Food Chem Toxicol 45:2219-2227

19. Klein V, Chajès V, Germain E, Schulgen G, Pinault M, Malvy D, Lefrancq T, Fignon A, Floch O Le, Lhuillery C, Bougnoux P (2000) Low alpha linolenic acid content of adipose breast tissue 
is associated with increased risk of breast cancer. Eur $\mathrm{J}$ Cancer 36:335-340

20. Kurzer MS, Xu X (1997) Dietary phytoestrogens. Annual Rev Nutr 17:353-381

21. Lake BG (1987) Preparation and characterization of microsomal fractions for studies on xenobiotic metabolism. In: Snell K, Mullock B (eds) Biochemical toxicology: a practical approach. IRL Press, Oxford, England, pp 183-215

22. Luijten M, Thomsen AR, van den Berg JA, Wester PW, Verhoef A, Nagelkerke NJ, Adlercreutz H, van Kranen HJ, Piersma AH, Sorensen IK, Rao GN, van Kreijl CF (2004) Effects of soyderived isoflavones and a high-fat diet on spontaneous mammary tumor development in Tg.NK (MMTV/c-neu) mice. Nutr Cancer 50:46-54

23. Luijten M, Verhoef A, Dormans JAMA, Beems RB, Cremers HWJM, Nagelkerke NJD, Adlercreutz H, Penalvo JL, Piersma AH (2007) Modulation of mammary tumor development in Tg.NK (MMTV/c-neu) mice by dietary fatty acids and life stagespecific exposure to phytoestrogens. Reprod Toxicol 23:407-413

24. Mortensen A, Sorensen IK, Wilde C, Dragoni S, Mullerova D, Toussaint O, Zloch Z, Sgaragli G, Ovesna J (2008) Biological models for phytochemical research: from cell to human organism. Br J Nutr 99(E Suppl 1):ES118-ES126

25. Muller WJ, Sinn E, Pattengale PK, Wallace R, Leder P (1988) Single-Step Induction of Mammary Adenocarcinoma in Transgenic Mice Bearing the Activated C-Neu Oncogene. Cell $54: 105-115$

26. Niemeyer HB, Honig DM, Kulling SE, Metzler M (2003) Studies on the metabolism of the plant lignans secoisolariciresinol and matairesinol. J Agric Food Chem 51:6317-6325

27. Parkin DM, Bray F, Ferlay J, Pisani P (2005) Global cancer statistics, 2002. CA Cancer J Clin 55:74-108

28. Patel PJ, Brocks DR (2009) The effect of oral lipids and circulating lipoproteins on the metabolism of drugs. Expet Opin Drug Metabol Toxicol 5:1385-1398

29. Penalvo JL, Heinonen SM, Nurmi T, Deyama T, Nishibe S, Adlercreutz H (2004) Plant lignans in soy-based health supplements. J Agric Food Chem 52:4133-4138

30. Penalvo JL, Nurmi T, Haajanen K, Al-Maharik N, Botting N, Adlercreutz H (2004) Determination of lignans in human plasma by liquid chromatography with coulometric electrode array detection. Anal Biochem 332:384-393

31. Penttinen P, Jaehrling J, Damdimopoulos AE, Inzunza J, Lemmen JG, van der SP, Pettersson K, Gauglitz G, Makela S, Pongratz I (2007) Diet-derived polyphenol metabolite enterolactone is a tissue-specific estrogen receptor activator. Endocrinology 148:4875-4886

32. Pietinen P, Stumpf K, Mannisto S, Kataja V, Uusitupa M, Adlercreutz H (2001) Serum enterolactone and risk of breast cancer: a case-control study in eastern Finland. Cancer Epidemiol Biomarkers Prev 10:339-344

33. Piller R, Chang-Claude J, Linseisen J (2006) Plasma enterolactone and genistein and the risk of premenopausal breast cancer. Eur J Cancer Prev 15:225-232

34. Rao GN, Ney E, Herbert RA (1997) Influence of diet on mammary cancer in transgenic mice bearing an oncogene expressed in mammary tissue. Breast Cancer Res Treat 45:149-158

35. Redinbaugh MG, Turley RB (1986) Adaptation of the bicinchoninic acid protein assay for use with microtiter plates and sucrose gradient fractions. Anal Biochem 153:267-271

36. Slamon DJ, Clark GM, Wong SG, Levin WJ, Ullrich A, McGuire WL (1987) Human breast cancer: correlation of relapse and survival with amplification of the HER-2/neu oncogene. Science 235:177-182

37. Takeuchi S, Takahashi T, Sawada Y, Iida M, Matsuda T, Kojima H (2009) Comparative study on the nuclear hormone receptor activity of various phytochemicals and their metabolites by reporter gene assays using Chinese hamster ovary cells. Biol Pharm Bull 32:195-202

38. Tan KP, Chen J, Ward WE, Thompson LU (2004) Mammary gland morphogenesis is enhanced by exposure to flaxseed or its major lignan during suckling in rats. Exp Biol Med (Maywood) 229:147-157

39. Thomsen AR, Mortensen A, Breinholt VM, Lindecrona RH, Penalvo JL, Sorensen IK (2005) Influence of Prevastein, an isoflavone-rich soy product, on mammary gland development and tumorigenesis in Tg.NK (MMTV/c-neu) mice. Nutr Cancer 52:176-188

40. Tou JC, Thompson LU (1999) Exposure to flaxseed or its lignan component during different developmental stages influences rat mammary gland structures. Carcinogenesis 20:1831-1835

41. Valsta LM, Kilkkinen A, Mazur W, Nurmi T, Lampi AM, Ovaskainen ML, Korhonen T, Adlercreutz H, Pietinen P (2003) Phyto-oestrogen database of foods and average intake in Finland. Br J Nutr 89(Suppl 1):S31-S38

42. Wang LQ (2002) Mammalian phytoestrogens: enterodiol and enterolactone. J Chromatogr B Analyt Technol Biomed Life Sci 777:289-309

43. Yamazaki H, Shimada T (1999) Effects of arachidonic acid, prostaglandins, retinol, retinoic acid and cholecalciferol on xenobiotic oxidations catalysed by human CYP450 enzymes. Xenobiotica 29(3):231-241

44. Zeleniuch-Jacquotte A, Adlercreutz H, Shore RE, Koenig KL, Kato I, Arslan AA, Toniolo P (2004) Circulating enterolactone and risk of breast cancer: a prospective study in New York. Br J Cancer 91:99-105 